
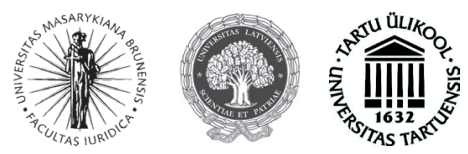

\title{
MAIN CHALLENGES AND PROSPECTS OF IMPROVING UKRAINIAN LEGISLATION ON CRIMINAL LIABILITY FOR CRIMES RELATED TO DRUG TESTING IN THE CONTEXT OF EUROPEAN INTEGRATION
}

\author{
Olena Grebeniuk \\ Lviv State University of Internal Affairs \\ 26 Horodoska Street, Lviv 79007 Ukraine \\ Telephone: (+380 50) 595 5533, (+380 50) 5041157 \\ E-mail: v_grebenyuk@ukr.net
}

Received on 16 August, 2013; accepted on 20 September, 2013

doi:10.13165/JUR-13-20-3-20

Annotation. The proposed article provides an overview of European and North American states' legislation, which regulates the procedure for pre-clinical research, clinical trials and state registration of medicinal products, as well as responsibility for its violation, analysis of the problems and prospects of adaptation of the national legislation to European legal space, particularly in the field of criminal and legal regulation of relations in the sphere of pre-clinical trials, clinical trials and state registration of medicine. The emphasis is put on the matter that inclusion of Article 321-2 into the Criminal Code of Ukraine leads to a false concurrence with other provisions of the Code. The author proposes to introduce recent EU legislation (Acquis Communautaire) on legal regulation of clinical trials and circulation of medicine into the law of Ukraine, clarify terminology related to Fundamentals of Ukrainian Legislation on Health Protection and the Special Part of criminal law, introduce criminal liability for legal entities that will provide effective control over negative effects of research centers' activity. It is suggested to develop legislative proposals to improve the provisions of the 
Criminal Code of Ukraine, which provide legal protection of relations arising in connection with pre-clinical research, clinical trials and state registration of medicinal products.

Keywords: EU legislation (Acquis Communautaire), drug testing, illegal experiments on human beings, the Nuremberg Code, the Declaration of Helsinki, criminal legislation, criminal liability for legal entities.

\section{Statement of the Problem}

The government of Ukraine would not be able to build a democratic and lawgoverned state, good cooperation of authorities with civil society and its positive impact on formation of a complex and wide range of public relations without a clearly defined and reasonable public policy. Legal policy plays an important role in addressing these issues. It intends to promote creation of positive law based on a deep study of social and legal regularities, an effective mechanism of legal regulation of relations in various spheres of public life, including combat of crime. Despite adoption and implementation of a new codified legislation, the current legislation of criminal cycle is still under development. A striking example of the «growing pains» in this field is the mechanism of legal regulation of relations in the field of pre-clinical studies, clinical trials and state registration of medicine.

European integration process, in which Ukraine is actively involved, provokes the review of many provisions of national legislation currently in force in the Ukraine, including the procedure for conducting pre-clinical studies, clinical trials and state registration of medicine.

Thus, the aim of this paper is to study both substance and effectiveness of the Ukrainian legislation introducing responsibility for crimes related to drug testing in the light of their genesis and further development, as well as the current international law and national standards in this area, especially in the EU and North American jurisdictions.

Although the comparative analyses of certain provisions of foreign criminal law in terms of liability for medical crimes were provided in the works of some Ukrainian and foreign scholars, including Balabko', Grinchak², Krylova, Karpenko, Myslyva, Tarasevych ${ }^{3}$, Chebotaryova ${ }^{4}$, Flori and others, however, these works do not consider the crimes that infringe the relations in the sphere of drug testing on humans. Among

1 Balabko, V. Criminal Liability of Medical Employees for Crimes Against Person's Life and Health. DPhil (Candidate) thesis, The National Academy of Prosecutors of Ukraine, 2013.

2 Grinchak, S. Breach of the Statue - Established Order of Human Organs or Tissues Transplantation: Foundations of Criminal Responsibility. DPhil thesis, Yaroslav Mudry National Law Academy of Ukraine, 2007.

3 Tarasevich, T. Medical Workers as Special Subject of Crime. DPhil (Candidate) thesis, V. Koretsky Institute of State and Law of the National Academy of Science of Ukraine, 2011.

4 Chebotareva, G. Legal Protection of Law and Order in Medicine. DPhil thesis, V. Koretsky Institute of State and Law of the National Academy of Science of Ukraine, 2011. 
foreign publications, special attention is paid to the work "Modern Medicine and Law" by Czech scholars Drhonets and Hollander, which provides for the comprehensive analysis of civil, criminal and family law issues of medical experiments, donation of organs and tissues and the new medical treatment employment.

\section{Historical Background of the Creation and Development of Mechanism of Drugs Testing Legal Regulation}

Analysis of historical background of appearance and development of a mechanism for legal regulation of drug testing on humans allows concluding that such studies have not been regulated by law for thousands of years and that testing of medicine, including drug tests on humans, was illegal.

Drug testing on humans was carried out back in the middle of the 20th century, which later became known as "inhumane experiments on human beings". It suffices to recall experiments in Nazi Germany in the 1930s and 1940s (Nazi programs of sterilization, euthanasia, experimentation on twins, etc.) $)^{5}$, as well as the research program of drugs testing on prisoners sentenced to extreme penalty (to death) in the former USSR from late 1930 s to early $1950 \mathrm{~s}^{6}$.

For the first time, the problem of protecting the rights of people participating in clinical trials was internationally addressed by the Nuremberg Military Tribunal, which delivered a verdict in the so-called Doctors' Trial based on the ten points that differentiate legal and illegal experimentation on humans. Only with the issuance of the Nuremberg Code in 1947, the efficiency of modern medicine became better considered, which in turn forced the community to define a boundary distinguishing between "the necessary scientific and research progress" and "illegal experiments on humans"”.

The main provisions of the Code were expanded and refined in later documents of the UN, WHO, WMA, CoE (the WMA Declaration of Helsinki - Ethical Principles for Medical Research Involving Human Subjects adopted in 1964, the CoE Convention for the Protection of Human Rights and Dignity of the Human Being with regard to the Application of Biology and Medicine: Convention on Human Rights and Biomedicine signed on April 4, 1997, etc.).

The thalidomide disaster of 1959-1961 became an impetus to the development of comprehensive rules for drug testing. The sale of a drug that was recommended as a sedative for pregnant women but had not undergone adequate pre-clinical and clinical trials began in Europe. As a result, cases of phocomelia ("seal limbs") were registered in 40 countries. It is a congenital deformity, in which the hands or feet are attached close to the body as seals have. From 1956 to 1962, more than 10 thousand children worldwide

5 Katz, D. Protection of Research Objects and Patients: Lessons of Nürnberg. Byoethics: Principles, Rules, Problems. M.: Edytoryal USSR, 1998, p.177-191.

6 Birshteyn, B. Experiments on Humans within NKVD. Chelovek. 1997, 5: 1-15.

7 Stefanov, A.; Maltsev, V. Bioethical Problems of Clinical Trials of Medical Products. In: Kundiyev, Y. (ed.). Anthology of Bioethics. Lviv: BaK, 2003, p. 349-358. 
were born with physical deformity as a side effect of taking thalidomide. After this tragedy, it became obvious that the usage of drugs should be controlled by the state and that state registration of a drug has to be based exclusively on the results of full and objective research, but not on subjective opinions of individual experts ${ }^{8}$.

In 1964, the World Medical Association adopted the Declaration of Helsinki, which became the basis for legislation on the principles of clinical trials developed by most European countries in the 1960s. In 1990 in Brussels, representatives of the United States, Japan and the European Union met to discuss the general rules for clinical trials. Similar meetings were held in the United States in 1993 and Japan in 1995, and already in 1996, an international expert working group elaborated an integrated document, the ICH Harmonized Tripartite Guideline for Good Clinical Practice (ICH GCP), and urged the participants of the harmonization process to legitimize it. In 1997, the ICH GCP entered into force in the USA, the EU and Japan'.

The article provides a deep analysis of legislation of different countries in order to define best practices in regulating the procedure for pre-clinical research, clinical trials and state registration of medicinal products, as well as responsibility for its violation. Primary attention is focused on European countries, since their legislation is in conformity with the EU law - a task, which Ukraine should fulfill in light of its European integration struggle and according to the upcoming Association Agreement. Besides, in order to introduce European experience in the Ukraine in the aforementioned area, it is important to examine carefully legislation of other countries, which, as Ukraine does, try to adapt their national legislation to European standards, regulating the procedure of pre-clinical research, clinical trials and state registration of medicinal products, as well as responsibility for its violation

\section{Pre-Clinical Research, Clinical Trials and State Registration of Medicines in Different Countries}

Belgium is known for its culture of conducting clinical trials both on the scientific level and in the pharmaceutical industry. Belgian Law as of May 7, 2004 concerning clinical trials implemented EUClinical Trials Directive 2001/20/EC. This law is regulated by three royal decrees to ensure implementing measures. In this context, Belgium has introduced the shortest procedure to allow for clinical research and clinical trials. These simplified procedures make it possible to convey the latest medical developments to

8 Kornatsky, V.; Silantyev, O. Problems of Medical Ethics at the Stage of Research and Introduction of Drugs in Historical Perspective. National Scientific Centre "Strazhesko Institute of Cardiology", Academy of Medical Sciences of Ukraine [interactive]. [accessed on 16-07-2013]. <http://www.rql.kiev. ua/cardio_j/2007/4/k\% EErnatskyy.htm>.

9 Kornatsky, V.; Silantyev, O. Problems of Medical Ethics at the Stage of Research and Introduction of Drugs in Historical Perspective. National Scientific Centre "Strazhesko Institute of Cardiology", Academy of Medical Sciences of Ukraine [interactive]. [accessed on 16-07-2013]. <http://www.rql.kiev. ua/cardio_j/2007/4/k\% EErnatskyy.htm>. 
patients as soon as possible. In accordance with the aforementioned EU directives and national Belgian law, the rights, safety and well-being of objects participating in clinical trials are provided. EU Clinical Trials Directive 2001/20/EC adopted into national law defines "responsibility for the initiation, management and financing of a clinical trial", legal responsibility is governed by the Civil Code and Criminal Code according to the level of harm caused to the patient (e.g., physical damage caused by negligence entails criminal liability).

The United Kingdom of Great Britain and Northern Ireland has The Medicines for Human Use (Clinical Trials) Regulations $2004^{10}$. Clinical trials without authorization or contrary to the provisions on clinical testing of a public market regulator of medicines the Medicines and Healthcare Products Regulatory Agency, cause the revocation of a license of manufacturer of medical products and equipment, and criminal liability, such as imprisonment up to two years and/or fines.

In the Kingdom of Spain, there are Law № 29 Use of medical and sanitary products as of June 26, 2006; Royal Decree 1344/2007 as of October, 11 regulating pharmacovigilance of medicinal products for human use, Royal Decree № 1345 as of October 10, 2007 Procedure for Licensing, Registration and Exemption of Medical Products, the Royal decree № 223 as of February 6, 2004 concerning clinical trials.

Canada has the Law on food and medicine products ${ }^{11}$; directives of Interagency advisory panel on research ethics ${ }^{12}$; regulations of the Department of Health of Canada, such as Clinical trials for natural health products ${ }^{13}$, Pre-clinical trial application consultation meeting ${ }^{14}$, Clinical trial applications ${ }^{15}$. In case of violation of the Food and Drug Regulations (for every single case), a fine of 500 to 1000 Canadian dollars should be paid and/or imprisonment from three months to three years might be applied.

The United States of America has a broad range of law in medical sphere. They include The Federal Food, Drug, and Cosmetic (FDC) Act of 1938; Insulin Amendment of 1941; Public Health Service Act of 1944; Penicillin Amendment of 1945; Miller Amendment of 1948; Durham-Humphrey Amendment of 1951; Color Additive Amendment of 1960; Kefauver-Harris Drug Amendments of 1962; Medical Device Amendments of 1976; Vitamins and Minerals Amendments of 1976; Orphan Drug Act

10 The Medicines for Human Use (Clinical Trials) Regulations 2004, SI 2004 No. 1031.

11 Food and Drugs Act (R.S.C., 1985, c. F-27).

12 Canadian Institutes of Health Research, Natural Sciences and Engineering Research Council of Canada, and Social Sciences and Humanities Research Council of Canada. Tri-Council Policy Statement: Ethical Conduct for Research Involving Humans. December, 2010 [interactive]. [accessed on 16-07-2013]. $<$ http://www.pre.ethics.gc.ca/pdf/eng/tcps2/TCPS_2_FINAL_Web.pdf $>$.

13 Health Canada. Clinical Trials for Natural Health Products Guidance. [interactive]. [accessed on 1607-2013]. <http://www.hc-sc.gc.ca/dhp-mps/prodnatur/legislation/docs/clini_trials-essais_nhp-psn-eng. php>.

14 Health Canada. Pre-Clinical Trial Application (CTA) Consultation Meeting. [interactive]. [accessed on 16-07-2013]. <http://www.hc-sc.gc.ca/dhp-mps/prodpharma/applic-demande/guide-ld/clini/cta_pre_application-eng.php>.

15 Health Canada. Clinical Trial Applications. [interactive]. [accessed on 16-07-2013]. <http://www.hc-sc. gc.ca/dhp-mps/prodpharma/applic-demande/guide-ld/clini/cta_application-eng.php>. 
of 1983; Fines Enhancement Laws of 1984 and 1987; Childhood Vaccine Act of 1986; Food and Drug Administration Act of 1988; The Prescription Drug Marketing Act of 1988; Generic Animal Drug and Patent Term Restoration Act of 1988; Anabolic Steroid Act of 1990; Safe Medical Devices Act of 1990; Generic Drug Enforcement of 1992; The Best Pharmaceuticals for Children Act of 2002 and Anabolic Steroid Control Act of 2004. There is an administrative and criminal liability for the violation of the abovementioned laws.

In the Federal Republic of Germany, the basic legislative act is a Federal Law on Medicinal Products (Arzneimittelgesetz/AMG). In Germany, the circulation of drugs is allowed only if that drug has met the licensing and registration requirements under the Law, or it has license of the European Commission, according to the EU instruction № 726/2004. This Law, the first edition of which was approved in 1961, is being constantly transformed and improved (the last version is dated August 1976), and the new version has also been repeatedly supplemented and transformed since its adoption, in particular in the context of the implementation of the EU requirements and rules into German national legislation. This process is permanent. For the first time provision on appropriate drug testing was introduced into the Act in 1964. The abovementioned Law on Medicinal Products provides for two types of liability for breach of any of its provisions: imprisonment and fines. Imprisonment, in general, can be for terms of one, three and, in very serious cases with severe widespread consequences, up to ten years. Concerning research and drug testing, the imprisonment is up to one year and fines are up to 25 thousand euros. An example of violation of the order, which results in monetary penalties, is failure to provide test results or their untimely provision.

In the Netherlands, there is Directive 2001/83/EC (2003/63/EC Directive, 2004/27/EC Directive amended and supplemented) on the Community Code relating to medicinal products for human use. These Directives codified and united EU legislation on medicinal products for human interests into a single document for clarity and rationalization of Directive 2001/20/EC (Clinical Trial Directive) on the approximation of the laws, regulations and administrative provisions of the Member States relating to the implementation of good clinical practice in the conduct of clinical trials on medicinal products for human use.

Further improvement of the legal regulation of clinical trials took place in 2005 with the adoption of Commission Directive 2005/28/EC of 8 April 2005 laying down principles and detailed guidelines for good clinical practice as regards investigational medicinal products for human use, as well as the requirements for authorisation of the manufacturing or importation of such products.

Commission Directive 2003/94/EC of 8 October 2003 laying down the principles and guidelines of good manufacturing practice in respect of medicinal products for human use and investigational medicinal products for human use, Council Directive 92/26/EEC concerning the classification for the supply of medicinal products for human use, the Law of the Kingdom of the Netherlands On medicines in 2007 (Geneesmiddelenwet), the Law of the Kingdom of the Netherlands On medical research 
on humans in 2003, the Law of the Kingdom of the Netherlands On Health Insurance in 2006 (Zorgverzekeringswet).

The most common type of liability for breach of preclinical studies and clinical trials is administrative responsibility. The maximum amount of the fine is 760,000 euros. Also, violation of clinical trials can be considered as a criminal offense (in the case of conscious creation of the situation endangering the life of the patient). However, the legislation establishes administrative liability for advertising and marketing products that are under preclinical study or in clinical trials. Responsibility for the practical study is assigned to the researcher. Typically, the sponsor is a pharmaceutical company, i.e. the developer of drugs, but the researcher can also perform the role of the sponsor if the research started on his initiative and then he takes full responsibility for its conduction. After registration of the medicinal product, a holder of marketing authorization is responsible for the sale of drugs. Appointment of the representative does not relieve the marketing authorization holder of legal liability.

Ireland. Traditional Herbal Medicinal Products Directive 2004/24/EC is integrated into the national regulations called The Medicinal Products (Control of Placing on the Market) Regulations of 2007 (SI No. 540 of 2007), The Good Clinical Practice Directive 2005/28/EC and The Good Manufacturing Practice Directive 2003/94/EC. Responsibility for violation of the law depends on the consequences that come from violating the law. On the administrative level, it may be revocation of a license and a fine.

In the Republic of Austria, there are the following regulating acts: 1. Federal Act as of 2 March 1983 on the manufacture and putting into circulation of drugs (the Drug Law - AMG; Bulletin of the Federal Law № 185/1983); 2. Order of the Minister of Health, Family and Youth regarding enterprises engaged in manufacturing, testing and putting into circulation of medicines (The order of drug production in 2009 - AMBO 2009); 3. Order of the Minister of Health and Women on the admission of finished dosage forms as of 2003 (Bulletin Federal Law number 487/2003). Legal liability for violation of pre-clinical research, clinical trials and state registration of medicinal products has both administrative and criminal aspects, including those at the stage of clinical trials on humans in the event of serious consequences to their health or death.

Greece has the following regulations: 1. Directive 2001/20/EC of the European Parliament and of the Council of 4 April 2001 on the approximation of the laws, regulations and administrative provisions of the Member States relating to the implementation of good clinical practice in the conduct of clinical trials on medicinal products for human use; 2. Directive 2001/83/EC of the European Parliament and of the Council of 6 November 2001 on the community code relating to medicinal products for human use; 3. Regulation (EC) No 726/2004 of the European Parliament and of the Council of 31 March 2004 laying down Community procedures for the authorisation and supervision of medicinal products for human and veterinary use and establishing a European Medicines Agency; 4. Guideline for Good Clinical Practice ICH Topic E 6(R1) of the European Medicines Agency on July 2002 CPMP/ICH/135/95. Administrative or criminal liability in this area relates mainly to corruption issues. 
In Estonia, questions concerning circulation and prescription of drugs, issuing trade licenses, clinical research and advertisement of drugs, pharmacovigilance and responsibility to ensure the safety, quality and efficiency of drugs used and facilitating their use for other purposes are regulated by the Medicinal Products Act of Estonia as of December 16, 2004, and also normative legal acts of the Ministry of Social Affairs of Estonia, namely Regulation No. 23 of the Minister of Social Affairs of 17 February 2005 Conditions and Procedure for Conducting Clinical Trials of Medicinal Product; Regulation No. 26 of 17 February 2005 Procedure for reporting serious adverse events occurring in clinical trials; Regulation No. 17 of 17 February 2005 Rules of procedure of medical ethics committee for clinical trials, a list of data to be submitted for obtaining approval, procedure for adoption of resolutions and format of application for obtaining approval.

According to Article 99 of the Medicinal Products Act Law on Medicines, responsibility for compliance with all aspects of the clinical trial of the medicinal product and its requirements is born by sponsor of the research. A physician, dentist or veterinarian, performing clinical research drug, is responsible for violation of duty only if it was done due to circumstances conditional on him. If the physician, dentist or veterinarian engaged in carrying out clinical research does this clinical research under the employment or other contract with a third party, the third party shall be jointly and equally liable with him. According to Article 105-112 of the Act, violations of the accounting and reporting of drugs, trade license for the drug and the delivery or distribution of medicinal products without a trade license or a medicinal product to which the pharmaceutical department did not issue import licenses or application license, violation of implementation of clinical trials of medicinal products and medical food, used in veterinary medicine, entail a fine of 300 penalty units or a fine of 3200 euros if the act is performed by a legal entity. Obstruction of public oversight or rejection of representation required for the inspection of documents or information, or failure to do it on time, false statement or representation of documents or information conducted by the legal entity in a form that does not allow supervising it lead to fine of up to $3200 \mathrm{CZK}$. Provisions of the General Part of the Penitentiary Code and Delictual Procedure Code are applied in the proceedings of the fault referred to in Articles 104-111 of this Act. According to Article 83 of the Penitentiary Code, court, prefecture police and tax and customs department may apply confiscation of property or object that served as the target of the implementation of offenses under Articles 104-106 of the Act. Pharmaceutical Department is the office, which leads out of court proceedings for violations under Articles 104-108, 110 and 111 of the Act. Health inspection is the office, which leads out of court proceedings for violations provided in Articles 104, 105, 110 and 111 of the Act admitted by a person that provides medical services. Healthcare Inspection is the office, which leads out of court proceedings for violations under Articles 104 and 111 of the Act, in the case of violations of health care standards. Prefecture police, customs and tax department are institutions that lead out of court proceedings for infringements provided in Articles 104-106 and 111 of the Act. Veterinary and Food Department is the office, which leads out of court proceedings for violations provided in Articles 109 and 111 of the Act. 
In the Italian Republic, there exists Law № 211 as of June 24, 2003 and the relevant decrees and orders of the Ministry of Health of Italy, full list of which is available at AIFA web-site.

In Bulgaria, there are also several regulations, such as the Law of the Republic of Bulgaria Medicinal products in human medicine as of April 13, 2012 and Ministry of Health Decree № 31 Definition of Good Clinical Practice as of August 17, 2007. Law of Bulgaria on Medicinal products in human medicine as of April 13, 2012 provides penalties and revocation of a license.

In the Republic of Armenia, pre-clinical study is not legally regulated. Currently, new draft Law on Medicines is being developed that includes such provisions. Clinical trials are regulated by Law on Health care and public service, Government Decision № 63 as of January 1, 2002 on approval of Procedure for clinical trials of new drugs in Republic of Armenia, Ministry of Health Decree № 05-N as of May 17, 2011 to approve documents required for obtaining permission to conduct clinical research and ethics committee charter. Law on Administrative Offences provides a fine, criminal responsibility provided in the case of counterfeit of medicines.

Talking about Georgia, there exists the Law of Georgia on Health care as of December 7, 2001, the Law of Georgia on Medicines and pharmaceutical activity as of April 7, 1997 with amendments on August 10, 2009, the Law of Georgia on Licenses and permits as of May 24, 2005, the Resolution of the Government of Georgia № 176 as of October 14, 2005 on Pharmacological and clinical studies of pharmaceutical products; the Resolution of the Government of Georgia № 153 as of January 9, 2005 on Conditions for issuing permits and licenses in the medical and pharmaceutical industries, the Resolution of the Government of Georgia № 385 as of December 17, 2010 on Conditions and procedures for licensing, Decree of the Ministry of Health and Social Affairs of Georgia № 325 as of October 13, 2009 on State registration of medicines and pharmaceutical products, Decree of the Ministry of Health and Social Affairs of Georgia № 344 as of October 23, 2009 on State registration of pharmaceutical products and their access to the market. Administrative liability in the form of fines and confiscation is foreseen as a punishment for violation of these laws.

Romania has also several laws and orders, such as Law № 95 dated April 14, 2006 On the reform of public health (Chapter XVII Medicines), the Minister of Health Order № 906 as of July 25, 2006 On approval of rules and analytical, pharmacological and clinical regulations of drug trials; Order № 615 as of June 1, 2010 On Amendments to the of rules and analytical, pharmacological and clinical regulations of drug trials, approved by the Minister of Health № 906/2006. In accordance with the Law №95/2006, guilty of violating the order of preclinical research, clinical trials and state registration of medicinal products, depending on the type and severity of the offense can be brought to disciplinary, civil, administrative or criminal liability.

In the Slovak Republic, legislation relating to pre-clinical or clinical trials, registration of medicines is a set of legal provision in the field of human medicine, veterinary medicine and medical devices contained in the Law №362/2011 amended. The Law provides responsibility for violation of the order of preclinical or clinical trials, registration of medicine defined by the Law №362/2011. This is the so-called 
administrative offence, for which penalty is provided by the Law. Sales of unapproved drugs on the market and the implementation of unauthorized clinical trials can be considered as crimes that fall under the Criminal Code (Law №301/2005).

Talking about Lithuania, there are the following regulations: 1. Preclinical study: Order of the Ministry of Health, the Ministry of Environment and the Ministry of Agriculture № 612/564/411 as of November 23, 2001 On the principles of good laboratory practice and compliance with monitoring procedures and evaluation; 2. Clinical trials: Law № 44-1247 of 2000 On the ethics of biomedical research; Law № X-709 as of June 22, 2006 On the pharmaceutical activity, Order of the Ministry of Health of Lithuania № V-435 as of May 31, 2006 On approval of the procedure for granting permission to conduct clinical trials, issuing certificates and permits to conduct clinical trials, the order of testing and monitoring, Order of the State Agency for the control of drugs under the Ministry of Health №1 A-1002 as of October 20, 2009 On some issues of permission to conduct clinical trials of medicinal products; Orders of the Director of the State Agency for the control of drugs under the Ministry of Health of Lithuania № 1A-72 as of January 26, 2011 On approval of rules verification of clinical trials, the approved test protocol of clinical trials registry and the approved protocols relating to clinical trials of drugs, № 1A-396 as of July 26, 2006 On the preparation and submission of an application to receive permit for clinical trials of medicinal products for humans and reporting on significant changes and the declaration of completion of testing, № 1A-663 as of October 30, 2006 On approval of the reporting on adverse events observed in clinical trials of drugs and adverse effects to investigational drugs, № 1A-205 as of April 19, 2005 On amending the Decree № 70 dated June 18, 2002 On requirements for clinical trials involving children, and № 1377-1A as of December 29, 2010 On establishment of Council on clinical trials and the approval of its provisions; 3. State registration of drugs: Laws of the Republic of Lithuania № X-709 as of June 22, 2006 On the pharmaceutical activity, №I-1562 as of October 03, 1996 On patients' rights and compensation for damage to their health, Decree of the Ministry Health of Lithuania № V-596 as of July 10, 2007 On the rules for granting licenses for the sale of drugs, a simplified procedure for registration of homeopathic medicinal products, a simplified procedure for registration of traditional herbal medicinal products, a special registration procedure of some homeopathic medicines mutual recognition and decentralized procedure for granting licenses for the sale of drugs, standards and analytical protocols, pharmacological and clinical studies, requirements for labeling and packaging of leaflets of medicines, list of excipients that must be indicated on the packaging and leaflet of a drug and procedure to permit the transfer of a license to sell drugs. Economic and non-economic damages caused by breach of the rights of patients shall be reimbursed in accordance with the procedure established by the Law on patients' rights and compensation for damage to their health, the Law on the ethics of biomedical research, the Civil Code, the Law on insurance and other legal acts. Sponsor and executor of biomedical research is responsible for the damage caused to health of the subject or the subject's death and for moral damage caused by biomedical research if it cannot be proved that the damage was caused as a result of actions unrelated to the biomedical research or deliberate actions of the subject. 
Finland is governed by the following regulations: Reporting of adverse drug reactions 2/2012; Labeling and package leaflets for medicinal products 1/2010; Reporting adverse drug reactions 1/2005; Medicines Act 395/1987 (amendments up to 1340/2010 included); Medicines Decree (amendments up to 69/2011 included); Decree of the Ministry of Social Affairs and Health concerning activities of the Finnish Medicines Agency subject to fees (1395/2011); Veterinary pharmacovigilance 1/2012; Amendment of administrative regulation 1/2009 concerning applying for and maintaining a marketing authorization and registration for a medicinal product $4 / 2011$; Parallel import of medicinal products 6/2010; Pharmacovigilance 5/2010; Clinical trials on medicinal products for veterinary use $3 / 2010$; Labeling and package leaflets for medicinal products 1/2010; Product defects 4/2009; Applying for and maintaining a marketing authorization and registration for a medicinal product 1/2009; Good manufacturing practice 5/2007; Good distribution practices for pharmaceutical wholesalers 4/2007; Clinical trials on medicinal products in human subjects 1/2007.

Finland legislation provides only two types of liability for violation of pre-clinical study, clinical trials and state registration of medicinal products: penalties (Sections 27-28 of the Medical Act of Finland from 1987 with additions in 2010) or revocation of license to carry out professional activities in the local market with the relevant informing of the European Commission about the fact. Thus, penalties are determined by the court based on the seriousness of violations and the level of interaction between the pharmaceutical company with state regulatory agencies in pre-clinical research, clinical trials and state registration of medicinal products. Typically, penalties are applied in exceptional cases and it is not a common practice in Finland.

In the Kingdom of Sweden, there are a few regulations, which include Regulation LVFS 2003:6 as of June 26, 2003 on clinical trials of medicinal products for humans; Regulation LVFS 2006:1 as of March 3, 2006 on the general principles of clinical trials of medicinal products for humans.

The Kingdom of Denmark has one main regulation, which is the Law of Denmark On Medicines, governing the permit and control of drugs, their manufacture, storage and work with drugs. It establishes rules to report adverse reactions to drugs and drug advertising. The law also governs issuance of permits for clinical testing in humans.

In the case of violation of the Law of Denmark On Medicines or corresponding EU legislation on medicines or other regulations in force in the area of drugs, the most common form of legal responsibility is a fine. In some cases, Danish legislation provides for criminal penalties and imprisonment for a term of 4 to 18 months. Legal entities (companies) can also be held criminally responsible, pursuant to Part V of the Criminal Code of Denmark. Minister of Health of Denmark has the right to terminate the use of legal liability when the fine is imposed. The Danish Medicines Agency of the Ministry of Health of Denmark can decide on a settlement agreement in the case, where a person has committed a violation, plead guilty and agreed to pay the fine within the specified time limit.

Norway also has several laws on the matter, which include the Law On Medical Research as of June 20, 2008, the Law On Medicines as of April 12, 1994, Guidelines 
for clinical trials of medicines for people as of October 30, 2009 (Forskrift om klinisk utprøving av legemidler til mennesker). According to Section 54 of the Law On Medical Research as of June 20,2008, violation of pre-clinical research, clinical trials and state registration of drugs is punishable by imprisonment for 1 year or a fine. In the case of violation, which leads to particularly complex effects, punishment may be extended up to three years in prison.

In Hungary, there also exist some regulations, which include Law On Healthcare № CLIV (1997); Law On Amendments to the Law on Medicines for human use and other laws regulating the market of drugs № XCV (2005); Resolution of the Government of Hungary № 235/2009 as of October 20, 2009 On granting permission for medical research on humans, clinical trials test drugs used in human clinical trials and medical devices for human use; Order of the Minister of Health of Hungary № 52/2005 as of September 18, 2005 On the use of medicinal products for human use.

According to paragraphs 1-8 of Article 20 and paragraphs 1-5 of Article 21 of the Law №XCV (2005) On Amendments to the Law on Medicines for human use and other laws regulating the market of drugs, civil liability is applied.

The Republic of Croatia is governed by regulations, which can be divided into two groups: 1. Law of the Republic of Croatia On medicines; 2. Law of the Republic of Croatia On medical products, Order of the Ministry of Health and Welfare of the Republic of Croatia On clinical trials of drugs and good clinical practice, Order of the Ministry of Health and Welfare of the Republic of Croatia On pharmacovigilance; On the basic requirements, qualifications, the quality management system registered in the list of manufacturers and reports about drugs and evaluation of drugs; On good practices, conditions of authorization for wholesale and import-export traffic of medical devices; On a method of quality control of medicinal products; About bioavailability and bioequivalence of drugs. In the case of violation of the abovementioned laws, administrative and criminal liability is foreseen.

The Czech Republic also has a set of rules: Law of Czech Republic № 378/2007 On medicines with the latest amendments; the Government Resolution № 226/2008 On standards of clinical practice and additional supplements clinical trials; № 228/2008 On the registration of medicines with the latest amendments. Paragraphs 103-109 of the Law of the Czech Republic № 378/2007 On Medicines provides for a fine of 50,000 to 3 million CZK or prohibition to engage in the relevant activities.

The Republic of Serbia has one main law, which is Law of the Republic of Serbia On drugs and medical devices as of May 7, 2010 and which provides for administrative and criminal liability for violation of its provisions.

On the contrary, the Republic of Macedonia has several regulations, which include Law On medicines and medical equipment; Instructions for applicants for clinical trial in accordance with the Law on medicines and medical equipment; Regulations on the procedure and the clinical trial and maintenance documentation, Instructions on the principles of good clinical practice, Regulation on order and procedures for pharmacological, toxicological and clinical testing of drugs, Regulation on the procedure and ways to control the quality of drugs. 
In case of the violation of the Law On medicines and medical equipment, such as if a clinical trial is carried out in violation of the Declaration of Helsinki and other international agreements signed or without presenting the results of analytical and pharmacological-toxicological studies or research affecting human genetic code, or insurance of persons involved in the trial in the case when damage to health is not done, the Law provides for a fine of 25,000 to 50,000 euros. If analytical, pharmacologicaltoxicological and clinical tests are carried out without complying with certain statutory conditions to premises, equipment and personnel, principles of good practice, and without permission from the Ministry of Health and if participants of the trial are not informed about its purpose, nature and potential risks, a fine of 15,000 to 30,000 euros is imposed.

In Bosnia and Herzegovina, there are the following regulations: the Law $O n$ drugs and medical equipment (2008); Instruction on how to control the quality of drugs (2009); Guidelines for monitoring deficiencies in the quality of medicines (2009); Rules for collecting and monitoring side effects of medicines and medical devices (2009); Provisions for clinical trials of Medicinal Products and Medical Devices (2010); Regulation on medical devices (2010); Regulations on the procedure for granting permission for sale of drugs (2011); Regulation on the conditions and procedures for licensed laboratories (2010); Decision on procedures for obtaining permission to import dangerous drugs that are approved for sale in Bosnia and Herzegovina (2011); Standards of good clinical practice in clinical trials (2012).

Section VI of the Law On medicines and medical equipment (2008) establishes penalties for violation of pre-clinical research, clinical trials and state registration of medicinal devices. Articles 131-135 of the Law establish penalties for various types of administrative violations in this area. The minimum fine is 1500 convertible marks (about 750 euros), in particular for failing to notify $\mathrm{BiH}$ Agency for medicines and medical supplies to terminate production or commercial sale of certain drugs (paragraph (b) of Article 135). The maximum penalty provided by the Law is 100 thousand convertible marks (about 50 thousand euros) and a person will be charged for such treatment in commercial circulation of drugs and medical devices that have not received permission actions and are not aligned with or directly contrary to the decision of pharmaceutical inspector. Fines for individuals, who make decisions within the legal entities, range from 3 thousand convertible marks (1.5 thousand euros) to 10 thousand convertible marks (5 thousand euros). Article 127 of the Law defines the powers of pharmaceutical inspectors who, in the case of violation, may suspend work of the legal entities, confiscate medications and drugs that are distributed without permission or are used in criminal activities and other offenses, prohibit the advertising of medicines that do not comply with the Law and prohibit legal business activities of the legal entities for non-compliance with the Law.

In Montenegro, there exist quite a few regulations on the matter, such as Law of Montenegro On medicine (2011), Law of Montenegro On medications, Law of Montenegro On veterinary activities, Law of Montenegro On the Control of substances that can be used to produce drugs and Law of Montenegro On Combating drug abuse. 
According to the legislation of Montenegro, violation of pre-clinical research, clinical trials and state registration of medicinal products results in de-licensing of the entity.

For a long time, Ukraine did not have clearly defined legal framework for regulation of relations in the sphere of drug circulation. Only in 1996, the Law of Ukraine on Medicinal Products came into effect and set the requirements for legitimacy of clinical trials of drugs and authorization procedures ${ }^{16}$. In particular, clinical trials are allowed with a written consent of the patient (volunteer) to participate in clinical trials or a written consent of his legal representative to conduct clinical trials involving a minor or an incapacitated patient. The patient or his legal representative shall obtain all information about the nature and possible consequences of the trials, characteristics of the tested pharmaceutical drug, its expected efficiency and risk level. The leader of clinical trials must stop such trial or its particular stages in the event of a threat to the health or life of the patient as the result of such trials, as well as after the request of the patient or his legal representative was received.

In 2004, Ukraine adopted the National Program on harmonization of the legislation of Ukraine with the EU legislation ${ }^{17}$. According to this program, clinical trials in the Ukraine shall be regulated by the legislation harmonized with the EU requirements and must comply with applicable directives of the European Parliament and the EU Council, such as the Directive 2001/20/EC of the European Parliament and of the Council, the Declaration of Helsinki, the CoE Convention for the Protection of Human Rights and Dignity of the Human Being with regard to the Application of Biology and Medicine: Convention on Human Rights and Biomedicine, the UN Convention on the Rights of the Child, the Guidelines issued by the International Conference on Harmonization of Technical Requirements for Registration of Pharmaceuticals for Human Use (ICH) and legally adapted in the EU (CPMP/ICH/135/95 (E6), CPMP/ICH/137/95 (E3), CPMP/ ICH/291/95 (E8), the Directive 2001/83/EC of the European Parliament and of the Council, etc.

\section{Main Aspects}

The process of Ukraine's integration into the international system of clinical trials was initiated in 1996, and already in 2003-2006, there was a rapid increase in the number of clinical trials as well as research centers. In the recent years, the field of clinical trials in the Ukraine moved from the phase of active formation to the phase of swift growth, as it is evidenced by the increasing number of international multi-centered clinical trials approved in the country (36 clinical trials in 2006, 177 in 2010, 201 in 2011 and 361 clinical trials in 2012, 330 of which are international multi-centered ones). In 2010, more than 2,500 locations in clinical trials were approved in the Ukraine, involving about 30,000 patients, which comprises only $10-15 \%$ of Ukraine's potential, according

16 Law of Ukraine on Medicines. Bulletin of the Verkhovna Rada of Ukraine. 1996, 22: 86.

17 Law of Ukraine on National Program Adaptation of Ukraine's Legislation to the Norms of the European Union. Bulletin of the Verkhovna Rada of Ukraine. 2004, 29: 367. 
to experts. There have been concerns that the Ukraine is an attractive region for clinical trials because it belongs to the group of countries with average income level and such concerns are supported by the opinion of legal counsels, who study the responsibility of health professionals or crimes against human life and health. According to law enforcement bodies of Ukraine, medical institutions do not make evaluation of their own expenses during clinical trials. A significant amount of funds is received by researchers, specifically doctors registered as private entrepreneurs, rather than medical institutions. Out-payments are determined by customer companies sponsoring the research, thus, creating conditions for prejudicing medical institutions. In addition, life and health insurance agreements are usually not concluded with patients. Customer companies conclude only insurance agreements of third-party property liability, while the Ukrainian legislation provides for the conclusion of life and health insurance agreements with patients $^{18}$.

According to acting legislation of Ukraine, a mandatory part of clinical trials is their compliance with the legislation regulating relationships in this area, monitoring the observance of human rights, safety conditions, ethical and moral standards, and confidentiality of participants in such trials. As to liability for violation of these rules, the legislation of Ukraine contains provisions for criminal liability for the breach of legal procedures for circulation and clinical trials of medicines, namely improper performance of duties with regard to children's life safety and healthcare (Article 137 of the Criminal Code of Ukraine (CC)), improper performance of duties by a member of medical or pharmaceutical institution (Article 140 of the $\mathrm{CC}$ ), violation of rights of a patient (Article 141 of the CC), illegal experimentation on a human being (Article 142 of the CC) and illegal disclosure of confidential medical information (Article 145 of the $\mathrm{CC})$.

Recently, the Criminal Code has been substantially amended with regard to provisions concerning liability for offenses related to counterfeiting, pre-clinical study, clinical trials and state registration of medicines. This step is related to the ratification of the Council of Europe Convention on the Counterfeiting of Medical Products and Similar Crimes involving Threats to Public Health by the Verkhovna Rada of Ukraine. The provisions of this Convention define the responsibility of the state-party to criminalize a number of acts that threaten public health.

Thus, Article 321-1 providing for liability for drug falsification or circulation of illegal medicine was introduced into the new edition of the Criminal Code of Ukraine. The Code was also supplemented by a new Article 321-2, establishing liability for violation of pre-clinical research procedures, clinical trials and state registration of medicines ${ }^{19}$.

18 Security Service of Ukraine. Letter No.8/3/3-8131 as of September 27, 2012, Concerning Provision of Information (Responding to Letter № 04-19/3-1955 as of September 14, 2012. Materials of the Verkhovna Rada of Ukraine Committee on Legislative Support of Law Enforcement.

19 Law of Ukraine on Amendments to Certain Legislative Acts of Ukraine to Strengthen Responsibility for Fraud or Circulation of Counterfeit Medicines. Bulletin of the Verkhovna Rada of Ukraine. 2013, $28: 300$. 
Despite the fact that the initiative of the new wording of Article 321-1 of the Criminal Code and amending the Code with Article 321-2 belongs to the Government of Ukraine, the Ministry of Healthcare of Ukraine stated, without questioning the need to strengthen the criminalization of falsification of medicines, that the establishment of criminal liability for violation of pre-clinical research procedures, clinical trials and state registration of drugs triggered the substitution of concepts between research of new drugs and falsification of medicines. As for pre-clinical research, clinical trials and state registration of medicines in the Ukraine, this procedure is strictly regulated by law, which is fully harmonized with the requirements of the European Community and meets the current directives of the European Parliament and the Council ${ }^{20}$.

It should be noted that the Verkhovna Rada of Ukraine almost immediately (within a few months after Article 321-2 was added to the Criminal Code) registered a draft law to cancel criminal liability for violation of pre-clinical research procedures, clinical trials and state registration of medicines. This legislative proposal was justified due to the fact that Chapter II of Special Part of the Criminal Code already contained provisions related to liability for certain types of violations of procedures of clinical trials of medicines, namely Article 141 and Article 142 of the Criminal Code that directly compete with the Article $321-2$ of the $\mathrm{CC}^{21}$.

According to experts of the American Chamber of Commerce in Ukraine in European law or relevant international practices, there are no analogues of the provisions of criminal liability for the above-mentioned offenses related to drugs in Ukrainian legislation. There is a common belief that this will lead to termination of pre-clinical research and clinical trials in the Ukraine and limit access of patients to participation in clinical trials, which is sometimes the last hope for a better quality of life through the access to new drugs ${ }^{22}$. The European Business Association representing the interests of foreign business in Ukraine and comprising over 900 companies has the same opinion. Thus, its appeal to the government of Ukraine contains recommendation to abolish Article $321-2$ of the CC, which establishes the excessive, disproportionate liability and excess pressure on health professionals involved in clinical trials. In addition, "the implementation of this article is also dangerous for patients with severe diseases, especially such diseases as cancer and neurological disorders; and if talking about the liability of medical and pharmaceutical workers, the existing criminal law (Articles 139142 of the Criminal Code of Ukraine) already establishes criminal responsibility"23.

20 Ministry of Health of Ukraine. Conclusion № 14.01-02/D-1/13/2362/13466 as of 27.09.2012. Casefile of the Draft Law of Ukraine 'On Amendments to the Criminal Code of Ukraine Concerning the Abolition of Criminal Liability for Violation of the Order of Pre-clinical Research, Clinical Trials and State Registration of Medicinal Products', Reg. No.11129.

21 Draft Law of Ukraine 'On Amendments to the Criminal Code of Ukraine Concerning the Abolition of Criminal Liability for Violation of the Order of Pre-clinical Research, Clinical Trials and State Registration of Medicinal Products', Reg. No.11129.

22 Ibid.

23 EBA. Appeal № 931/2012/13 as of September 5, 2012. Case-file of the Draft Law of Ukraine 'On Amendments to the Criminal Code of Ukraine Concerning the Abolition of Criminal Liability for Violation of the Order of Pre-clinical Research, Clinical Trials and State Registration of Medicinal Products', Reg. No.11129. 
It should be noted that the content of Article 321-2 of the $\mathrm{CC}$ is designed in such a manner that any willful violation of the rules of pre-clinical research, clinical trials and state registration of medicines is considered to be a complete offense, starting from the moment of its commitment.

Analysis of regulations that govern pre-clinical research of drugs suggests that it involves chemical, physical, biological, microbiological, pharmacological, toxic and other scientific research in order to study their specific activity and safety and conducted before clinical trials. This study includes laboratory pre-clinical drug research and experiments on laboratory animals in order to study its specific activity and safety. It is apparent from the contents of legal documents that pre-clinical research of drugs involves usage of animals of mammals group in the vast majority of relevant research.

Therefore, this type of research does not create a risk to life and health, and thus there is no object of criminal assault meaning danger to the public. However, it is stated about the commitment of an act on the stage of pre-clinical trials, involving subjects such as drugs, not illegal drugs. This may mean that there are no grounds to consider pre-clinical trials of drugs as bearing a risk to human life and health. So, concerning this section, it can be noted that there has been a false criminalization, which contains the features of unreasonable, excessive and improper criminalization.

Clinical trial of a medical product is a research work aimed at any research involving humans as research subjects. Clinical research is a fundamental scientific activity, which is indispensable for developing and choosing new, more effective and safer drugs. Recently, the role of clinical trials has increased with the introduction of the principles of evidence-based medicine. The main goal of such principles is to ensure that such clinical trials are not based on personal experience of a doctor, but are confirmed by scientific evidence. At the same time, such experiments cannot replace experiments on laboratory animals or tissues. Therefore, clinical trials are necessary at the final stage. Such research is rather dangerous and does have consequences for those, who serve as subjects for experiments. Each experiment carries risks for a patient. The very nature of the relationship between the researcher and the subjects requires different objectives, such as knowledge for the former and improvement of health for the latter ${ }^{24}$.

Violation of the procedure for registration of medicines is distinguished from the other two offenses under Article 321-2 of the Criminal Code in the degree of social danger and should, in the view of the author, be written in various articles or various parts of the same article of the Criminal Code to establish penalties, which would correspond to the degree of a social risk of each. As for illegal testing on humans, Article 142 of the Criminal Code provides two separate cases of penal violations, namely conducting clinical trials without the written consent of the patient or conducting trials on minors or incapacitated. In this case, the criminal responsibility for these violations occurs only in the presence of severe consequences or the death of a patient. Article 141 of the Criminal Code provides sufficient criminal protection of relations, arising in connection with clinical trials causing death or other serious consequences for patients' health. The 
object of clinical trials of medicine is the life and health of humans. Therefore, such act is included in Chapter II of Special Part of the Criminal Code (crime against life and health of a person). An additional object is a set procedure for clinical trials.

Similar violations attributed to the disposition of Article 321-2 of the CC, namely the violation of the order of pre-clinical research, clinical trials and state registration of medicines, infringe the established procedure of pre-clinical and clinical trials, procedure of circulation of medical drugs (the main object of the crime), and the life and health of the person may serve as an additional object (Part 3 of Article 321-2 of the Criminal Code).

The above-mentioned statements indicate that all other violations of pre-clinical, clinical research and creating by such actions a real risk to the life of the patient without socially dangerous consequences had remained outside the scope of criminal law until the provisions of Article 321-2 of the CC were set.

Thus, matching the content of Articles 141, 142 and 321-2 of the Criminal Code reveals both similarities, as evidence of a crime provided for these items, and their differences. Supplementing the Criminal Code with Article 321-2 created artificial competition of provisions with other ones of the Code, which the author suggests should be removed.

There is a question whether there was an objective need for criminalization of acts that infringe the established order of preclinical research, clinical trials and registration of medicines and supplementation of the Criminal Code with Article 321-2.

As Melnyk states, "Periodic change of the criminal law (predicting new provisions, elimination of existing ones, changing their wording, etc.) is an objective necessity, is a reaction to the development of crime as a complex socio-political phenomenon that is constantly changing, adjusting and adapt to real economic, political, legal and other conditions". At the same time, in his opinion, criminalization should be preceded by a thorough and in-depth study of these problems, resulting in a need to get clear and unambiguous answers to a series of questions and, above all, to the following ones: (1) is there a problem, which can be solved by criminalization, (2) whether the nature and degree of a risk (danger) are sufficient to establish it as an offense, (3) whether there is a need for a new criminal law provision that would provide for the responsibility for such action (how efficient are other possible means to solve the problem or whether criminal means are suitable and how they can be effective), and 4) how to fix the criminal act in criminal law (which essential features should be provided as mandatory). Ignoring these problems or not obtaining clear and reasonable answers to them can cause errors in criminalization of acts with different legal, social and other consequences arising therefrom ${ }^{25}$.

Moreover, as the analysis of legal practice shows, it is extremely difficult to bring to criminal responsibility actors involved in crimes of improper execution of obligations,

25 Melnyk, M. Foreword. In: Shvets, E.; Grytsak, V.; Vasylkevych, Y.; Hatselyuk, V. Legislative Implementation of Penal Policy: Analysis of Drafting of the Verkhovna Rada of Ukraine of 5 th Convocation on Criminal Law. Kyiv: Atika, 2008, p. 244. 
concerning protection of life and health of a child (Article 137 of the CC), improper performance of professional duties by medical or pharmaceutical personnel (Article 140 of the CC), violation of rights of a patient (Article 141 of the $\mathrm{CC}$ ) and illegal disclosure of medical information (Article 145 of the $\mathrm{CC}$ ).

A significant reason for this is the fact that there is a terminological inconsistency between the medical and criminal law in the Ukraine, e.g., the Fundamentals of Ukrainian Legislation on Health Protection ${ }^{26}$ refers to conduction of biomedical experiments, research experiments, therapeutic experiments, but Article 141 of the Criminal Code of Ukraine provides for grounds of criminal responsibility for illegal conduction of clinical trials, Article 142 provides for responsibility for irregularities in performance of biomedical, psychological or other experiments on humans, and Article 321-2 provides for responsibility for violation of procedures of pre-clinical research, clinical trials and state registration of medicines. Appositely, international instruments related to the same matter also use different terms, specifically "medical experiments on human beings" (the Nuremberg Code), "medical research on humans" (the Declaration of Helsinki) and "biomedical researches with experiments on a human (humans)" (the Tokyo and Venice Declaration). Different terms are found in specialized literature, such as research, experiment, medical research and research on humans. Thus, the author concludes that the concepts of testing, research and experiment are used interchangeably.

\section{Conclusions}

In conclusion, it is worth to mention that it is highly important for Ukraine to further adapt its legislation to the new EU standards in the field of legal regulation of clinical trials and circulation of medicines, clarifying terminology of Fundamentals of the Ukrainian legislation on health protection, and the Special Part of criminal law. It is also essential to improve the criminal law and its application. With the addition of Article 321-2 of the Criminal Code, artificial competition with other provisions of the Code appeared and this requires amendments. In this connection, an object of a research, the objective side of the crimes provided in Article 321-2 and Article 141 of the CC and clarification of differences between these notions of crime should be studied. Based on this, legislative proposals should be developed to improve the provisions of the Criminal Code providing for legal protection of relations arising in connection with pre-clinical research, clinical trials and state registration of medicines. An urgent task is also to implement the liability for legal persons into national criminal law that will ensure effective control over negative impacts of research centers and further integration of Ukraine into the European clinical trials control system. 


\section{References}

Balabko, V. Criminal Liability of Medical Employees for Crimes Against Person's Life and Health. DPhil (Candidate) thesis, The National Academy of Prosecutors of Ukraine, 2013.

Basic Law of Ukraine on Public Health. Bulletin of the Verkhovna Rada of Ukraine. 1993, 4: 19.

Baulin, Y.; Borisov, V.; Gavrish, S. The Criminal Code of Ukraine: Scientific and Practical Commentary. 4th ed. Kharkiv: LLC 'Odyssey', 2008, p. 1208.

Birshteyn, B. Experiments on Humans within NKVD. Chelovek. 1997, 5: 1-15.

Canadian Institutes of Health Research, Natural Sciences and Engineering Research Council of Canada, and Social Sciences and Humanities Research Council of Canada. Tri-Council Policy Statement: Ethical Conduct for Research Involving Humans. December, 2010 [interactive]. [accessed on 16-07-2013]. <http://www.pre.ethics.gc.ca/ pdf/eng/tcps2/TCPS_2_FINAL_Web.pdf $>$.

Chebotareva, G. Legal Protection of Law and Order in Medicine. DPhil thesis, V. Koretsky Institute of State and Law of the National Academy of Science of Ukraine, 2011.

Commission Directive 2005/28/EC of 8 April 2005 laying down principles and detailed guidelines for good clinical practice as regards investigational medicinal products for human use, as well as the requirements for authorisation of the manufacturing or importation of such products. [2005] OJ L 91/13.

Draft Law of Ukraine 'On Amendments to the Criminal Code of Ukraine Concerning the Abolition of Criminal Liability for Violation of the Order of Pre-clinical Research, Clinical Trials and State Registration of Medicinal Products', Reg. No.11129.

EBA. Appeal № 931/2012/13 as of September 5, 2012. Case-file of the Draft Law of Ukraine 'On Amendments to the Criminal
Code of Ukraine Concerning the Abolition of Criminal Liability for Violation of the Order of Pre-clinical Research, Clinical Trials and State Registration of Medicinal Products', Reg. No.11129.

Food and Drugs Act (R.S.C., 1985, c. F-27).

Grinchak, S. Breach of the Statue - Established Order of Human Organs or Tissues Transplantation: Foundations of Criminal Responsibility. DPhil thesis, Yaroslav Mudry National Law Academy of Ukraine, 2007.

Health Canada. Clinical Trial Applications. [interactive]. [accessed on 16-07-2013]. $<$ http://www.hc-sc.gc.ca/dhp-mps/ prodpharma/applic-demande/guide-ld/clini/ cta_application-eng.php>.

Health Canada. Clinical Trials for Natural Health Products Guidance. [interactive]. [accessed on 16-07-2013]. <http://www. hc-sc.gc.ca/dhp-mps/prodnatur/legislation/ docs/clini_trials-essais_nhp-psn-eng.php>.

Health Canada. Pre-Clinical Trial Application (CTA) Consultation Meeting. [interactive]. [accessed on 16-07-2013]. <http:// www.hc-sc.gc.ca/dhp-mps/prodpharma/ applic-demande/guide-ld/clini/cta_pre_ application-eng.php>.

Katz, D. Protection of Research Objects and Patients: Lessons of Nürnberg. Byoethics: Principles, Rules, Problems. M.: Edytoryal USSR, 1998, p.177-191.

Kornatsky, V.; Silantyev, O. Problems of Medical Ethics at the Stage of Research and Introduction of Drugs in Historical Perspective. National Scientific Centre "Strazhesko Institute of Cardiology", Academy of Medical Sciences of Ukraine [interactive]. [accessed on 16-07-2013]. $<$ http://www.rql.kiev.ua/cardio_j/2007/4/ $\mathrm{k} \%$ EErnatskyy.htm>.

Law of Ukraine on Amendments to Certain Legislative Acts of Ukraine to Strengthen Responsibility for Fraud or Circulation of Counterfeit Medicines. Bulletin of the Verkhovna Rada of Ukraine. 2013, 28: 300. 
Law of Ukraine on Medicines. Bulletin of the Verkhovna Rada of Ukraine. 1996, 22: 86.

Law of Ukraine on National Program Adaptation of Ukraine's Legislation to the Norms of the European Union. Bulletin of the Verkhovna Rada of Ukraine. 2004, 29: 367.

Melnyk, M. Foreword. In: Shvets, E.; Grytsak, V.; Vasylkevych, Y.; Hatselyuk, V. Legislative Implementation of Penal Policy: Analysis of Drafting of the Verkhovna Rada of Ukraine of 5th Convocation on Criminal Law. Kyiv: Atika, 2008.

Ministry of Health of Ukraine. Conclusion № $14.01-02 / \mathrm{D}-1 / 13 / 2362 / 13466$ as of 27.09.2012. Case-file of the Draft Law of Ukraine 'On Amendments to the Criminal Code of Ukraine Concerning the Abolition of Criminal Liability for Violation of the Order of Pre-clinical Research, Clinical Trials and State Registration of Medicinal Products', Reg. No.11129.

Ministry of Health of Ukraine. Order of Preclinical Study of Medications and Expertise of a Clinical Study of Drugs No. 944 of December 14, 2009.

Parliament and Council Directive 2001/20/ EC of 4 April 2001 on the approximation of the laws, regulations and administrative provisions of the Member States relating to the implementation of good clinical practice in the conduct of clinical trials on medicinal products for human use. [2001] OJ L121/34.

Parliament and Council Directive 2001/83/EC of 6 November 2001 on the Community code relating to medicinal products for human use. [2001] OJ L 311/67.
Security Service of Ukraine. Letter No.8/3/38131 as of September 27, 2012, Concerning Provision of Information (Responding to Letter № 04-19/3-1955 as of September 14, 2012). Materials of the Verkhovna Rada of Ukraine Committee on Legislative Support of Law Enforcement.

Stefanov, A.; Maltsev, V. Bioethical Problems of Clinical Trials of Medical Products. In: Kundiyev, Y. (ed.). Anthology of Bioethics. Lviv: BaK, 2003, p. 349-358.

Tarasevich, T. Medical Workers as Special Subject of Crime. DPhil (Candidate) thesis, V. Koretsky Institute of State and Law of the National Academy of Science of Ukraine, 2011.

The Medicines for Human Use (Clinical Trials) Regulations 2004, SI 2004 No. 1031.

Word Medical Association Declaration of Helsinki. Ethical Principles for Medical Research Involving Human Subjects. [interactive]. [accessed on 16-07-2013]. $<$ http://www.wma.net/e /policy/b3.htm>.

Zukoski, J. (President of the American Chamber of Commerce in Ukraine). Letter to the Verkhovna Rada of Ukraine, the Cabinet of Ministers of Ukraine and the Ministry of Health of Ukraine № 12-365 as of September 20, 2012. Case-file of the Law of Ukraine № 5065-VI dated July 5, 2012 'On Amendments to Certain Legislative Acts of Ukraine on Increased Liability for Fraud or Circulation of Counterfeit Medicines'.

\section{UKRAINOS IૃSTATYMŲ LEIDYBOS IŠŠŪKIAI IR PERSPEKTYVOS NUSTATANT BAUDŽIAMAJĄ ATSAKOMYBĘ UŽ NUSIKALTIMUS, SUSIJUSIUS SU VAISTŲ BANDYMAIS: EUROPOS SAJUNGOS KONTEKSTAS}

\section{Olena Grebeniuk}

Lvovo valstybinis vidaus reikalų universitetas, Ukraina

Santrauka. Straipsnyje pažymima, kad vykdomame integracijos i Europa procese Ukrainoje identifikuojamas poreikis persvarstyti ir peržiūrèti daugybę nacionalinès teisès 
aktu, tarp ju ir tuos, kurie regulinoja ikiklinikiniu vaistu tyrimu procedūras, klinikinius tyrimus ir valstybine medicininiu produktu registracija. Ilga laika Ukrainoje nebuvo aiškiai apibrěžtos teisiniu santykiu, susiklostančiu vaistu cirkuliacijos procese, reglamentacijos. Tik $1996 \mathrm{~m}$. buvo priimtas ir ìsigaliojo Ukrainos įstatymas „Dèl vaistu“", o $2004 \mathrm{~m}$. buvo patvirtinta nacionaline programa dèl Ukrainos istatymu derinimo su Europos Sajungos teise. Pagal šia programa, vaistu tyrimai Ukrainoje turi büti vykdomi pagal teisès aktus, kurie yra atitinkantys Europos Bendrijos reikalavimus ir direktyvas.

Pastaraisiais metais klinikiniu bandymu srityje Ukrainoje vyksta staigus augimas, kas lemia nuolat auganti sertifkuotu tarptautiniu mastu klinikiniu tyrimu skaiču.

Straipsnyje apžvelgiama Europos, Šiaurès Amerikos ir kitu valstybiu (siekiančiu integracijos i bendraja Europos teisinę erdve) vaistu tyrimu srities teisine reglamentacija. Diskutuojamos problemos ir perspektyvos, su kuriomis susiduriama derinant nacionaline teise su Europos Sajungos teise akcentuojant baudžiamosios teises aspektus. Demesys yra kreipiamas i dirbtini konflikta tarp naujojo 321-2 straipsnio ir kitu Baudžiamojo kodekso nuostatu. Autore identifikuoja poreiki labiau pasirengti nauju Europos Sajungos dokumentu, susijusiu su klinikiniu tyrimu reguliavimu ir vaistu apyvarta, taikymui, terminijos, vartojamos pagrindiniuose Ukrainos teisès aktuose, reguliuojančiuose sveikatos sfera, bei Baudžiamajame kodekse, aǐkinima, baudžiamosios atsakomybes juridiniams asmenims ịtvirtinima, kas lemtu veiksminga tyrimo centru veiklos kontrole.

Siüloma vystyti įstatymu leidybos iniciatyvas, susijusias su poreikiu tobulinti Ukrainos baudžiamojo kodekso nuostatas, kurios nustato teisine apsanga santykiams, atsirandantiems vykdant ikiklinikinius tyrimus, klinikinius tyrimus ir valstybine medicinos produktu registracija.

Reikšminiai žodžiai: Europos įstatymu leidyba, vaistu testavimas, kriminaliniai eksperimentai su žmonemis, Niurnbergo kodeksas, Helsinkio deklaracija, baudžiamieji įstatymai, baudžiamoji juridiniu asmenu atsakomybè.

Olena Grebeniuk, Lvovo valstybinio vidaus reikalų universiteto Baudžiamosios teisès katedros doktorantė, Ukrainos valstybinès mokesčių administracijos Tyrimų departamento vyresnioji ypatingų bylų tyrejja. Mokslinių tyrimų kryptys: baudžiamoji teisè, farmacijos teisè.

Olena Grebeniuk, PhD student of Criminal Law Department of Lviv State University of Internal Affairs, Senior investigator for particularly important cases of Main Investigation Department of the State Tax Administration. Research interests: criminal law, pharmacy law. 